\title{
Assessments and Targeted Rehabilitation Therapies for Diaphragmatic Dysfunction in Patients with Chronic Obstructive Pulmonary Disease: A Narrative Review
}

\author{
Yanjun Chen', Peijun Li', Jie Wang $\mathbb{B}^{2}$, Weibing Wu $\mathbb{D}^{\prime}$, Xiaodan $\mathrm{Liu}^{3}$ \\ 'Department of Sports Rehabilitation, Shanghai University of Sport, Shanghai, People's Republic of China; ${ }^{2}$ School of Physical Education and Sport \\ Training, Shanghai University of Sport, Shanghai, People's Republic of China; ${ }^{3}$ School of Rehabilitation Science, Shanghai University of Traditional \\ Chinese Medicine, Shanghai, People's Republic of China
}

Correspondence: Xiaodan Liu, School of Rehabilitation Science, Shanghai University of Traditional Chinese Medicine, Cailun Road No. 300, Pudong New District, Shanghai, People's Republic of China, Tel +86-I5800668700; +86-2I-58323I58, Email hzhp403@l26.com; Jie Wang, School of Physical Education and Sport Training, Shanghai University of Sport, Chang Hai Road No. 399, Yang Pu District, Shanghai, People's Republic of China, Tel +86-I88I758I075, Email 1536273I3@qq.com

\begin{abstract}
Purpose: This review summarizes the characteristics, assessment methods, and targeted rehabilitation therapies of diaphragm dysfunction in patients with chronic obstructive pulmonary disease (COPD).

Methods: Extensive literature was searched in PubMed, the Cochrane Library, Web of Science, Chinese National Knowledge Infrastructure Database, Wanfang, and SinoMed.

Results: Under the influence of oxidative stress, inflammation, and other factors, the diaphragm function of patients with COPD changes in mobility, muscle strength, thickness, and thickening. In patients with COPD, diaphragm mobility can be assessed using ultrasound, X-ray fluoroscopy, and magnetic resonance imaging. Diaphragmatic strength can be measured by transdiaphragmatic pressure and maximal inspiratory pressure. Diaphragmatic thickness and thickening can be assessed using ultrasound. Rehabilitation therapies targeting the diaphragm include diaphragmatic breathing, diaphragm-related manual therapy, and phrenic nerve electrical stimulation. Diaphragmatic breathing is safe, simple, and not limited by places. Diaphragmatic manual therapies, which require patient cooperation and one-on-one operation by a professional therapist, are effective. Phrenic nerve electrical stimulation is suitable for patients with severe conditions. These therapies improve the diaphragmatic function, lung function, dyspnea, and exercise capacity of patients with COPD.
\end{abstract}

Conclusion: The diaphragmatic function is commonly assessed in terms of mobility, strength, thickness, and thickening. Diaphragmatic targeted rehabilitation therapies have proven to be efficient, which are recommended to be included in the pulmonary rehabilitation strategy for patients with COPD.

Keywords: chronic obstructive pulmonary disease, diaphragmatic dysfunction, assessment, diaphragmatic breathing, manual therapy, phrenic nerve electrical stimulation

\section{Introduction}

Chronic obstructive pulmonary disease (COPD) is a common, preventable, and treatable respiratory disease characterized by persistent respiratory symptoms and airflow limitation. ${ }^{1}$ A 2018 epidemiological survey showed that $13.7 \%$ of Chinese adults aged 40 years and older have COPD. ${ }^{2}$ This disease causes more than three million deaths worldwide each year, and it is one of the three leading causes of death. ${ }^{3}$ Direct medical costs account for $33.33-118.09 \%$ of annual per capita income. ${ }^{4}$ The diaphragm is the most important muscle for human respiratory movements and is responsible for approximately $60-80 \%$ of the ventilation workload during respiration. ${ }^{5}$ Given the increased respiratory load, oxidative stress, inflammation, and other factors, reduced and altered muscle fibers, diaphragmatic dysfunction occurs in COPD 
patients. $^{6-9}$ The dysfunction of the diaphragm in patients with COPD is inextricably linked to reduced pulmonary function, increased dyspnea, and reduced exercise tolerance. ${ }^{10,11}$ Therefore, the role of the diaphragm in respiratory diseases, especially in chronic respiratory diseases, has received increased attention and is considered an important target of interventions for COPD disease progression and improving the pulmonary function, dyspnea, and exercise capacity of patients. ${ }^{12,13}$

In recent years, diaphragmatic dysfunction in COPD patients has gained increasing attention. ${ }^{9,14}$ The main clinical manifestations of diaphragmatic dysfunction include reduced mobility, decreased muscle strength, and changes in diaphragmatic thickness (Tdi) and thickening. Diaphragmatic mobility in patients with COPD can be assessed through ultrasound, X-ray fluoroscopy, and magnetic resonance imaging (MRI), whereas diaphragmatic muscle strength can be measured with transdiaphragmatic pressure (Pdi) and maximal inspiratory pressure (MIP). The thickness and thickening of the diaphragm can also be assessed by ultrasound. Diaphragm rehabilitation therapies refer to rehabilitation treatments in which the diaphragm is the treatment target, and they include diaphragmatic breathing Training, manual therapy, and phrenic nerve electrical stimulation. The enhancement of diaphragm function can lead to improvements in pulmonary function, subjective perception, and exercise capacity in COPD patients. A literature search revealed that diaphragmatic rehabilitation treatment modalities have not been reviewed. Therefore, we also explored different rehabilitation therapies in terms of operation, effects, and suggestions for COPD patients with diaphragm dysfunction in this narrative review.

\section{Diaphragm Dysfunction in Patients with COPD Decreased Diaphragm Mobility}

Reduced diaphragmatic mobility is a typical manifestation of diaphragmatic dysfunction in patients with COPD. Diaphragm mobility is lower in patients with COPD than in healthy normal subjects. ${ }^{7,11,15-17}$ Diaphragmatic mobility correlates with pulmonary function, subjective perception, and exercise capacity in these patients. Fu et al ${ }^{11}$ showed that diaphragm mobility in patients with COPD decreased with increasing severity, which was determined using the Global Initiative for Chronic Obstructive Lung Disease (GOLD) classification. Moreover, diaphragmatic mobility is related to forced expiratory volume in one second /forced vital capacity (FEV1/FVC), the percentage of predicted values of FEV1 (FEV1\%pred), and the percentage of inspiratory volume predicted. The percentage of maximal inspiratory capacity predicted is positively correlated, where diaphragm mobility is negatively correlated with residual air volume/total lung volume as a percentage of the predicted value. Zhang et $\mathrm{al}^{17}$ observed that the motion of the diaphragm in patients with COPD is positively correlated with FEV1 and total lung volume. Similar findings were found in the study by Hellebradova et al. ${ }^{14}$ These results suggested that diaphragm mobility is positively correlated with pulmonary function. A negative correlation was found between diaphragm mobility and modified Medical Research Council Dyspnea Scale (mMRC) scores. ${ }^{17}$ Diaphragm mobility decreases with the increased degree of dyspnea in patients with COPD. ${ }^{15,17-19}$ Diaphragmatic mobility is positively correlated with the 6-minute Walking Distance (6MWD) ${ }^{19,20}$ In conclusion, diaphragm mobility is closely related to pulmonary function, subjective perception, and exercise capacity in patients with COPD and decreases with disease progression.

\section{Decreased Diaphragm Muscle Strength}

Decreased diaphragmatic muscle strength is also a major manifestation of diaphragmatic dysfunction in patients with COPD. Zheng et $\mathrm{al}^{21}$ reported that MIP, maximum Pdi, and maximum sniff Pdi were significantly lower in the severe COPD group than in the normal control group, and twitching Pdi was significantly lower in the mild and severe COPD groups than in the normal control group. Polkey et $\mathrm{al}^{22}$ proposed the reduced ability of the diaphragm to produce twitch Pdi in patients with severe COPD. The MIP of patients with COPD was lower than that of control groups and significantly reduced from the moderate to the severe stage of the disease. ${ }^{23-25}$ This result showed that patients with different degrees of COPD severity have impaired diaphragmatic strength. In the study of Zheng et al, ${ }^{21}$ the decrease in twitch Pdi in the COPD group was positively correlated with FEV1. Yu et $\mathrm{al}^{26}$ observed that the maximum Pdi was significantly negatively correlated with the partial pressure of arterial carbon dioxide and significantly positively correlated with vital capacity, deep inspiratory volume, FVC, and maximum inspiratory volume. These results showed 
that the severity of impairment in a patient's pulmonary function, especially ventilation, increases with the decline in diaphragmatic strength.

\section{Changes in Tdi and Thickening}

Changes in Tdi and thickening in COPD patients are also signs of diaphragm dysfunction. Baria et $\mathrm{al}^{27}$ showed no significant difference in Tdi between COPD patients and normal subjects except for the severe air residual subgroup. Zhang et $\mathrm{al}^{28}$ reported a significant decrease in Tdi in COPD patients compared with the controls. However, the Tdi significantly increased in the mild COPD group compared with the control group. Smargiassi and Zhang et al ${ }^{28,29}$ suggested that Tdi changes are closely related to air trapping.

Similar findings were found in the changes in diaphragmatic thickening fraction (TF). Rittayamai et $\mathrm{al}^{30}$ reported $^{2}$ significantly higher diaphragm tidal thickening fraction during resting breathing in patients with COPD than in controls; the severe COPD was approximately twice as high as in controls. During the Muller maneuver, the maximal TF exhibited a significantly positive correlation with post-bronchodilator FEV1 and MIP and a negative correlation with total lung capacity, residual volume, and residual volume/total lung capacity. Zhang et $\mathrm{al}^{28}$ also observed similar changes in TF. However, apart from airway obstruction, Eryuksel et $\mathrm{al}^{31}$ reported no association between TF and exacerbation frequency, the COPD Assessment Test and mMRC scores, or GOLD ABCD risk/symptom assessments. Tdi and thickening were strongly associated with air trapping in COPD patients, but correlations with other clinical symptoms could not be determined.

The changes in Tdi and thickening may be due to the fragile balance between adaptive and deleterious biological mechanisms in the diaphragm in stable COPD. Adaptive changes predominate in the early stages. As the disease progresses, deterioration, nutritional abnormalities, and aging dominate. This condition can cause the balance to tip toward a negative phenotype. ${ }^{8,9,32}$ Therefore, the changes in thickness and thickening are more pronounced in patients with severe COPD.

\section{The Pathophysiology of the Diaphragm in COPD}

Due to the hyperinflated state of a patient's lungs, which results from the chronic airflow limitation and thereby depresses the diaphragm and reduces its ability to generate tension. ${ }^{8}$ On the other hand, elastic load (eg, caused by changes in the chest wall and lung parenchyma), resistance (eg, caused by airway stenosis), and threshold (eg, caused by intrinsic positive end-expiratory pressure) increases in patients, resulting in an overload of the diaphragm contraction preload and increased work of breathing. ${ }^{7,9}$ The increase load induces the diaphragm to produce fatigue-resistant changes and increase in the proportion of type I fibers. ${ }^{7}$ In patients with mild to moderate COPD, Doucet et al ${ }^{6}$ observed that the diaphragms of patients with COPD had higher proportions of type I fibers and showed a relative decrease in type IIA fibers. Testelmans et $\mathrm{al}^{33}$ attained similar findings in the diaphragms of patients with severe COPD. Zhang et al ${ }^{34}$ reported a similar observation in a rat model. If change in muscle strength is considered only in terms of diaphragm muscle fibers, type I fibers produce less isometric contraction than type II fibers. ${ }^{35}$ Thus, change in fatigue resistance occurs at the cost of a decrease in diaphragmatic strength.

Oxidative stress, inflammation, and other factors contribute to the development of diaphragmatic dysfunction in COPD patients. Barreiro et $\mathrm{al}^{36}$ found that the mRNA and protein levels of TNF- $\alpha$ and IL- 6 in the diaphragm of patients with severe COPD and normal weight were significantly higher than those of healthy people. Increased production of oxidants in the mitochondrial and membrane compartments of diaphragm fibers has been reported in severe COPD. ${ }^{37,38}$ Different scholars reported alterations in signaling pathways closely associated with diaphragm fiber atrophy, particularly the upregulation of nuclear factor- $\mathrm{KB}$ pathway, ubiquitin-proteasome pathway, and muscle growth inhibitor and downregulation of myocyte assay protein $1 .{ }^{6,9,13,39}$ These changes are closely associated with diaphragm dysfunction in COPD patients. The diaphragm atrophies, the cross-sectional area is reduced. Several authors observed a reduction in the cross-sectional areas of diaphragm type I and II muscle fibers in patients with moderate and severe COPD. ${ }^{6,33}$ Zhang et $\mathrm{al}^{34}$ discovered a reduction in diaphragm type I and II fiber diameters in a rat model of COPD. 


\section{Assessments for Diaphragmatic Function of COPD Assessments of Diaphragmatic Mobility}

Diaphragmatic mobility assessment in patients with COPD can be performed with noninvasive methods, such as ultrasound, X-ray fluoroscopy, and MRI. Ultrasound is easy to operate, inexpensive, safe, and harmless. ${ }^{40}$ It is now a widely used clinical modality for diaphragm mobility assessment. Boussuges et $\mathrm{al}^{41}$ suggested that in ultrasound examination of diaphragmatic mobility, the lower limit is close to $0.9 \mathrm{~cm}$ for women and $1 \mathrm{~cm}$ for men during quiet breathing and close to $3.7 \mathrm{~cm}$ for women and $4.7 \mathrm{~cm}$ for men during deep breathing. Ultrasound examination can be performed at the bedside and is therefore preferred for bedridden patients. However, examination results are susceptible to factors, such as the subject's level of exertion and operator experience. ${ }^{41} \mathrm{X}$-ray fluoroscopy has the advantage of facilitating the observation of diaphragm movement in real time, but the images lack clarity, and the subjects are at risk of radiation exposure, which can be used as an initial assessment. ${ }^{42,43}$ MRI evaluation allows the acquisition of images of the entire coronal and sagittal planes of the diaphragm and facilitates the unilateral, local, or complete observation of abnormal diaphragm movements. ${ }^{43,44}$ This method is an effective tool for assessing diaphragm mobility because of its clear imaging and objective accuracy. However, MRI examinations are time consuming, expensive, and need to be selected with caution. Currently, a standardized method or standard parameters for assessing diaphragm mobility in patients with COPD are unavailable, and current methods and values are limited by age, gender, body mass index, and other factors. Most studies have judged changes in diaphragm mobility based on changes in values before and after treatment or comparison with data from control groups.

\section{Assessments of Diaphragmatic Strength}

Diaphragm strength can be assessed by Pdi and MIP. Pdi represents the pressure difference between the lower esophagus and stomach, and the pressure measured in the lower esophagus and stomach represents pressure in the thoracic cavity and abdominal cavity, respectively. The pressure is often measured by passing balloon catheters through the nose, following local anesthesia of the nasal mucosa and pharynx. ${ }^{45}$ The patient consciously controls breathing movement, and pressure in the chest and abdominal cavity changes. An operator evaluates the strength of the diaphragm muscle with the measured pressure difference. ${ }^{45}$ Pdi includes maximal, maximal sniff, and twitch Pdi. The maximal and maximal sniff Pdi can be measured with Muller maneuvers and maximal nasal inspiratory maneuvers, respectively. Twitch Pdi can be measured during the transcutaneous electrical (magnetic) stimulation of the phrenic nerve. ${ }^{45}$ Maximal sniff and maximal Pdi greater than $80 \mathrm{cmH}_{2} \mathrm{O}$ for men and $70 \mathrm{cmH}_{2} \mathrm{O}$ for women can rule out clinically evident diaphragm weakness. ${ }^{46}$ A twitch Pdi greater than $10 \mathrm{cmH}_{2} \mathrm{O}$ during unilateral phrenic nerve stimulation or greater than $20 \mathrm{cmH}_{2} \mathrm{O}$ during bilateral phrenic nerve stimulation can rule out notable diaphragmatic weakness. ${ }^{46}$ Twitch Pdi is unaffected by subjective factors and can sensitively and objectively reflect the functional state of the diaphragm. Its repeatability is better than that of maximal and maximal sniff Pdi. ${ }^{21}$ Although the Pdi test can directly detect changes in diaphragmatic muscle strength, its operation is invasive. The process requires placing a balloon catheter into a patient's esophagus and stomach, and thus, its use in clinical practice is limited. ${ }^{46}$

MIP is the oral pressure generated by the subject inhaling with maximal effort in the functional residual air position. ${ }^{43,45}$ MIP greater than $80 \mathrm{cmH}_{2} \mathrm{O}$ can exclude diaphragmatic weakness. ${ }^{42}$ The MIP measures the muscle force of the entire respiratory muscle group and not the diaphragm alone. Therefore, MIP can be used as a reference indicator to determine diaphragm dysfunction but not the primary indicator. MIP testing is convenient and noninvasive but is susceptible to factors, such as subjective exertion, age, and lung volume. ${ }^{42}$

\section{Assessments of Tdi and Thickening}

Recognized Tdi and thickening measurements are performed by ultrasound: end-expiratory Tdi is the static measurement; the dynamic evaluation of the ratio of inspiratory to expiratory Tdi is reported as the thickening ratio (TR; inspiratory thickness/expiratory thickness) or thickening fraction (TF; (inspiratory thickness-expiratory thickness)/end-expiratory thickness). ${ }^{47}$ In normal individuals at rest, Tdi at functional residual capacity varies widely, ranging from $1.2 \mathrm{~mm}$ to $11.8 \mathrm{~mm}$, with group means ranging from $1.6 \mathrm{~mm}$ to $3.4 \mathrm{~mm}$. The lower limit of normal adults is $0.80 \mathrm{~mm}$ to $1.60 \mathrm{~mm}{ }^{48}$ 
A minimum of $20 \%$ increase in $\mathrm{TF}$ is normal. ${ }^{49}$ Tdi and thickening thresholds for the identification of diaphragm dysfunction in COPD patients are unavailable.

\section{Targeted Rehabilitation Therapies of COPD Diaphragm}

Currently, pulmonary rehabilitation is a beneficial measure to improve the pulmonary function, subjective perception, and exercise capacity of patients with COPD. Diaphragmatic rehabilitation is a category of comprehensive pulmonary rehabilitation. Common diaphragmatic rehabilitation modalities include diaphragmatic breathing training, manual therapy, and phrenic nerve electrical stimulation. In this section, we review these diaphragm-focused rehabilitation modalities.

\section{Screening Studies}

We screened studies using a methodology similar to that of a systematic review. ${ }^{50}$ To be closer to the current state of research, we included a wide variety of clinical studies.

\section{Inclusion Criteria}

1) Type of studies: clinical trials; 2) Participants: patients with stable COPD; 3) Intervention methods: experimental groups of randomized controlled trials, grouping trials, and self-controlled trials that received breathing training, manual therapy, or phrenic nerve electrical stimulation and control groups of randomized controlled trials that received drug treatment, sham treatment, and nursing; 4) Outcomes: A. Diaphragm function: diaphragmatic mobility, Pdi, MIP, Tdi, and TF; B. Lung Function: FEV1, FEV1\%pred, FVC, FEV1/ FVC, maximal mid-expiratory flow (MMEF), and maximal voluntary ventilation (MVV); C. Degree of dyspnea: mMRC; D. Functional exercise capacity: 6MWD.

\section{Exclusion Criteria}

1) duplicated data; 2) not clinical trials; 3 ) inconsistent with our intervention measures or interventions are combined with other rehabilitation measures.

\section{Data Collection}

Six databases (PubMed, the Cochrane Library, Web of Science, Chinese National Knowledge Infrastructure Database, Wanfang, and SinoMed) were used as data resources to retrieve clinical trials from 2011 to 2021. The search was conducted with the following keywords in Chinese or English: (Pulmonary Disease, Chronic Obstructive OR Chronic Obstructive Lung Disease OR Chronic Obstructive Pulmonary Disease OR COAD OR COPD OR Chronic Obstructive Airway Disease OR Airflow Obstruction, Chronic OR Chronic Airflow Obstruction) AND (diaphragmatic breathing OR diaphragmatic respiration OR abdominal breathing OR abdominal respiration OR diaphragmatic releasing technique OR diaphragmatic stretching technique OR external diaphragmatic pacing).

\section{Study Selection}

Two reviewers independently screened the studies in accordance with the inclusion and exclusion criteria. They used Endnote software to find and delete duplicate studies. They browsed the title and abstract to exclude irrelevant research, re-screened by reading the full text of the remaining studies, and then excluded studies that did not meet the inclusion criteria. When the two reviewers were inconsistent, a third party intervened to discuss and reach a consensus. Figure 1 outlines the screening process for studies. The results of the study screening are shown in Tables 1-3.

\section{Diaphragmatic Breathing Training}

Respiratory muscle training has been extensively studied because of its recognized effects. ${ }^{51-53} \mathrm{Xia}$ et al ${ }^{54}$ reported that respiratory muscle training improves diaphragmatic dysfunction in patients with COPD. Respiratory muscle training methods, such as resistance loading method, pressure threshold loading method, and carbon dioxide hyperventilation method, have been used to delay the weakening of diaphragmatic contractile function, improve pulmonary function, and enhance quality of life. In this part of the review, we choose to study the rehabilitative method of diaphragmatic breathing with the diaphragm as the focus. 


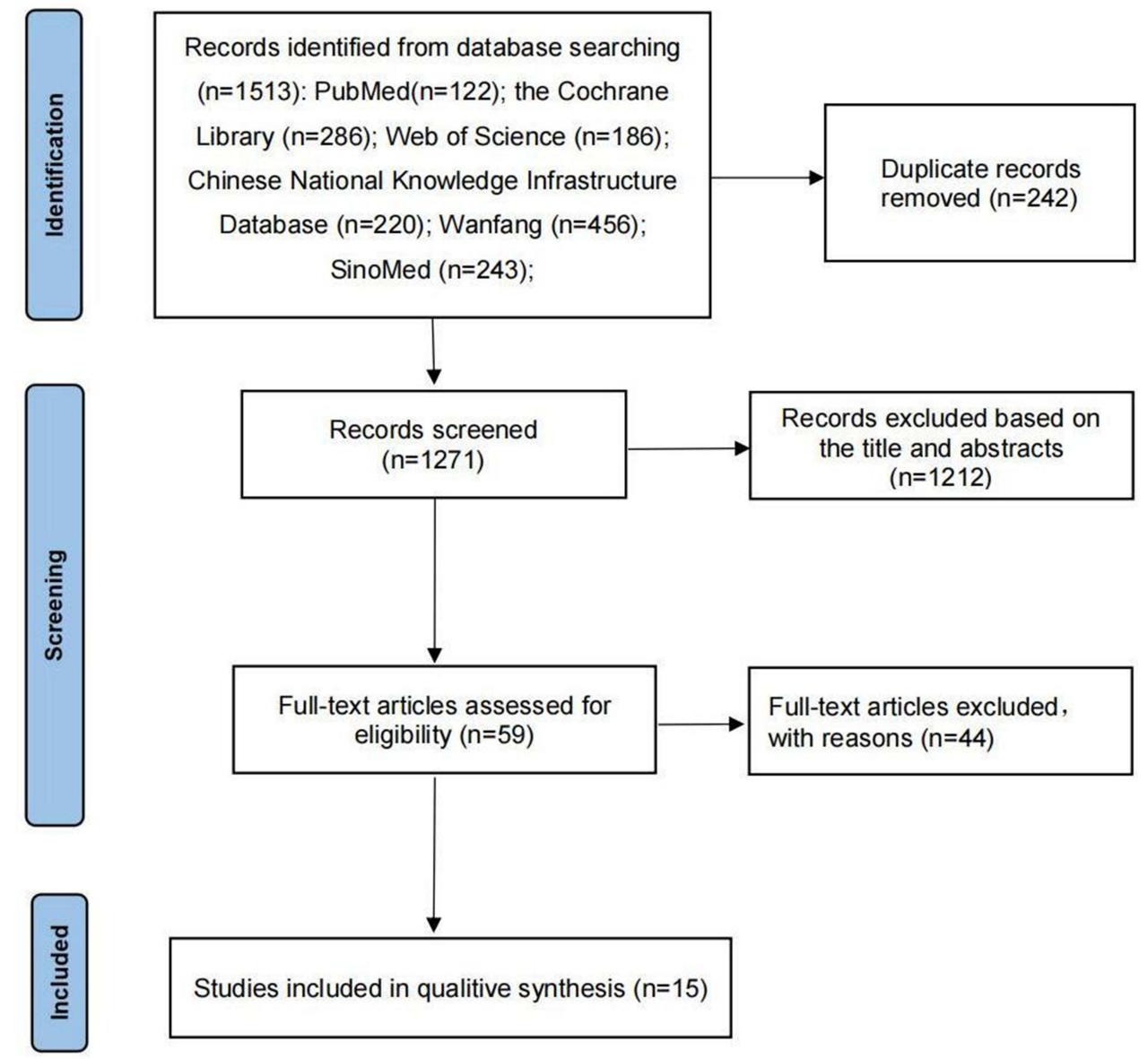

Figure I Systematic search flowchart.

During diaphragmatic breathing, a patient reduces the use of auxiliary respiratory muscles and completes respiratory movements with the activity of the diaphragm; thoracic activity is minimized, and abdominal movements during breathing is increased (Figure 2). ${ }^{55}$ The aim is to improve dyspnea, correct the patient's abnormal breathing pattern, increase the magnitude of diaphragmatic up and down movements, reduce the activation of auxiliary muscles, increase tidal volume, reduce functional residual capacity, and improve lung ventilation. ${ }^{56-58}$

\section{Clinical Application of Diaphragmatic Breathing Training}

Diaphragm breathing can improve diaphragmatic dysfunction, dyspnea, lung ventilation and exercise capacity of patients with COPD (Table 1). Yamaguti et $\mathrm{al}^{59}$ reported that after diaphragmatic breathing intervention, the diaphragmatic mobility of the diaphragmatic breathing group was higher than the baseline; in comparison between the groups, the diaphragmatic breathing group was better than the control group. This result directly proves that diaphragmatic breathing can improve diaphragmatic dysfunction. Two studies reported improvements in dyspnea. ${ }^{59,60} \mathrm{Ma}$ et $\mathrm{al}^{60}$ reported that the mMRC score of patients with moderate COPD is better than baseline. Yamaguti et al ${ }^{59}$ reported that the mMRC score of the diaphragmatic breathing group is lower than that of the control group. This finding shows that diaphragmatic breathing can alleviate the dyspnea of patients with COPD. Three studies used FVC, FEV1, and FEV1/FVC as indicators related to pulmonary ventilation function. ${ }^{60-62}$ Zhan et $\mathrm{al}^{62}$ found that the $\mathrm{FVC}$ of the diaphragmatic breathing group is better than that of the control group. Ma and Liu et $\mathrm{al}^{60,61}$ reported that the FVC, FEV1, and FEV1/FVC of the diaphragmatic breathing group are better than those at baseline. This finding shows that diaphragmatic breathing can improve the lung ventilation function of patients with COPD. Two studies mentioned the improvement of exercise performance. ${ }^{59,62} \mathrm{Ma}$ et $\mathrm{al}^{60}$ observed that the $6 \mathrm{MWD}$ in the diaphragmatic breathing group is longer than that before the 
Table I Studies of Diaphragmatic Breathing

\begin{tabular}{|c|c|c|c|c|c|c|}
\hline Study & $\begin{array}{c}\text { Experimental } \\
\text { Type }\end{array}$ & Group & Participants & Intervention & $\begin{array}{l}\text { Frequency and } \\
\text { Duration }\end{array}$ & Indicators \\
\hline $\begin{array}{l}\text { Yamaguti } \\
\text { et } \mathrm{al}^{59} \\
2012\end{array}$ & $\begin{array}{l}\text { Randomized } \\
\text { control trial }\end{array}$ & $\begin{array}{l}\text { Experimental } \\
\text { group/control } \\
\text { group }\end{array}$ & $15 / 15$ & $\begin{array}{l}\text { Diaphragmatic breathing+ } \\
\text { nursing care/ nursing care }\end{array}$ & $\begin{array}{l}3 \text { times/week } \\
4 \text { weeks }\end{array}$ & $\begin{array}{l}\text { Diaphragmatic } \\
\text { mobility }{ }^{* \&} \\
\text { mMRC } \downarrow^{*} \\
\text { 6MWD } \uparrow^{*}\end{array}$ \\
\hline $\begin{array}{l}\text { Ma et } \mathrm{al}^{60} \\
2014\end{array}$ & $\begin{array}{l}\text { Grouping } \\
\text { trial }\end{array}$ & $\begin{array}{l}\text { Mild group/ } \\
\text { moderate group }\end{array}$ & $25 / 35$ & Diaphragmatic breathing & $\begin{array}{l}2 \text { times/day } \\
\text { I year }\end{array}$ & $\begin{array}{l}\text { Mild group: } \\
6 \mathrm{MWD} \uparrow^{\&} \\
\text { Moderate group: } \\
\text { FEVI } \uparrow^{\&} \\
\mathrm{FEVI/FVC} \uparrow^{\&} \\
\mathrm{FVC} \uparrow^{\&} \\
\mathrm{mMRC} \downarrow^{\&} \\
6 \mathrm{MWD} \uparrow^{\&}\end{array}$ \\
\hline $\begin{array}{l}\text { Liu et al }{ }^{61} \\
2011\end{array}$ & $\begin{array}{l}\text { Randomized } \\
\text { control trial }\end{array}$ & $\begin{array}{l}\text { Experimental } \\
\text { group/control } \\
\text { group }\end{array}$ & $21 / 21$ & $\begin{array}{l}\text { Diaphragmatic breathing+ } \\
\text { medication/medication }\end{array}$ & $\begin{array}{l}4 \text { times/day } \\
30 \text { days }\end{array}$ & $\begin{array}{l}\mathrm{FEVI} / \mathrm{FVC} \uparrow^{\&} \\
\mathrm{FVC} \uparrow^{\&}\end{array}$ \\
\hline $\begin{array}{l}\text { Zhan } \\
\text { et } \mathrm{al}^{62} \\
2020\end{array}$ & $\begin{array}{l}\text { Randomized } \\
\text { control trial }\end{array}$ & $\begin{array}{l}\text { Experimental } \\
\text { group/control } \\
\text { group }\end{array}$ & $34 / 34$ & $\begin{array}{l}\text { Diaphragmatic breathing+ } \\
\text { nursing care/nursing care }\end{array}$ & $\begin{array}{l}2 \text { or } 3 \text { times/day } \\
\text { I year }\end{array}$ & $\mathrm{FVC} \uparrow^{*}$ \\
\hline
\end{tabular}

Notes: *Statistical difference between experimental and control groups $(P<0.05) ;{ }^{~}$ statistical difference between experimental groups before and after the experiment $(\mathrm{P}<0.05) ; \uparrow$, increase; $\downarrow$, decrease.

Abbreviations: 6MWD, 6 minutes walking distance; FEVI, forced expiratory volume in one second; FVC, forced vital capacity; mMRC, modified Medical Research Council Dyspnea Scale.

Table 2 Studies of Manual Therapy

\begin{tabular}{|c|c|c|c|c|c|c|}
\hline Study & $\begin{array}{l}\text { Experimental } \\
\text { Type }\end{array}$ & Group & Participants & Intervention & $\begin{array}{c}\text { Frequency } \\
\text { and Duration }\end{array}$ & Indicators \\
\hline 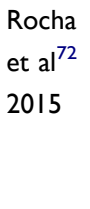 & $\begin{array}{l}\text { Randomized } \\
\text { control trial }\end{array}$ & $\begin{array}{l}\text { Experimental } \\
\text { group/control } \\
\text { group }\end{array}$ & $9 / 10$ & $\begin{array}{l}\text { Diaphragm release technique/fake } \\
\text { treatment }\end{array}$ & $\begin{array}{l}6 \text { times } \\
2 \text { weeks }\end{array}$ & $\begin{array}{l}\text { Diaphragmatic } \\
\text { mobility } \uparrow^{*} \\
\text { Inspiratory } \\
\text { volume }{ }^{*} \\
\text { 6MWD } \uparrow^{*}\end{array}$ \\
\hline 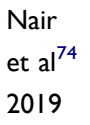 & $\begin{array}{l}\text { Randomized } \\
\text { crossover trial }\end{array}$ & $\begin{array}{l}\text { Experimental } \\
\text { group/control } \\
\text { group }\end{array}$ & $10 / 10$ & $\begin{array}{l}\text { Diaphragm stretching technique / } \\
\text { diaphragm release technique }\end{array}$ & I time & 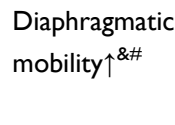 \\
\hline
\end{tabular}

Notes: *Statistical difference between experimental and control groups $(\mathrm{P}<0.05)$; ${ }^{\&}$ statistical difference between experimental groups before and after the experiment $(\mathrm{P}<0.05) ;{ }^{\#}$ statistical difference between control groups before and after the experiment $(\mathrm{P}<0.05)$; $\uparrow$, increase.

Abbreviation: 6MWD, 6-minute walking distance.

intervention. In the experiment of Yamaguti et al, ${ }^{59}$ the $6 \mathrm{MWD}$ in the diaphragmatic breathing group is longer than that in the control group.

Ma et $\mathrm{al}^{60}$ only observed 6MWD improvement in patients with mild COPD after diaphragmatic breathing intervention. After intervention, patients with moderate COPD showed improvements in lung ventilation function, mMRC, and 6MWD. This result may be ascribed to the fact that the function of mild patients is less impaired and that diaphragmatic breathing is a relatively gentle training method and thus exerts insufficient training effects on patients with mild COPD. 
Table 3 Studies of Phrenic Nerve Electrical Stimulation

\begin{tabular}{|c|c|c|c|c|c|c|}
\hline Study & $\begin{array}{c}\text { Experimental } \\
\text { Type }\end{array}$ & Group & Participants & Intervention & $\begin{array}{c}\text { Frequency and } \\
\text { Duration }\end{array}$ & Indicators \\
\hline $\begin{array}{l}\text { Cao et al }{ }^{82} \\
2020\end{array}$ & $\begin{array}{l}\text { Randomized } \\
\text { control trial }\end{array}$ & $\begin{array}{l}\text { Experimental } \\
\text { group/control } \\
\text { group }\end{array}$ & $30 / 30$ & $\begin{array}{l}\text { External diaphragm pacing } \\
+ \text { routine treatment / } \\
\text { Routine treatment }\end{array}$ & $\begin{array}{l}\text { I time/day } \\
20 \text { days }\end{array}$ & $\begin{array}{l}\text { Diaphragmatic } \\
\text { mobility } \uparrow^{*} \\
\text { MIP }{ }^{*} \\
\text { FEVI\%pred } \uparrow *\end{array}$ \\
\hline $\begin{array}{l}\text { Wang JC } \\
\text { et } \mathrm{al}^{83} 2019\end{array}$ & $\begin{array}{l}\text { Randomized } \\
\text { control trial }\end{array}$ & $\begin{array}{l}\text { Experimental } \\
\text { group/control } \\
\text { group }\end{array}$ & $40 / 40$ & $\begin{array}{l}\text { External diaphragm pacing } \\
+ \text { oxygen therapy+ } \\
\text { medication/oxygen therapy } \\
+ \text { medication }\end{array}$ & $\begin{array}{l}2 \text { times/day } \\
14 \text { days }\end{array}$ & $\begin{array}{l}\text { Diaphragmatic } \\
\text { mobility } \uparrow^{* \& \#} \\
\text { FEVI } \uparrow^{\& \#} \\
\text { FEVI/FVC } \uparrow^{\& \#} \\
\text { FVC } \uparrow^{* \& \#}\end{array}$ \\
\hline $\begin{array}{l}\text { Feng et al }{ }^{84} \\
2019\end{array}$ & $\begin{array}{l}\text { Randomized } \\
\text { control trial }\end{array}$ & $\begin{array}{l}\text { Experimental } \\
\text { group/control } \\
\text { group }\end{array}$ & $31 / 32$ & $\begin{array}{l}\text { External diaphragm pacing } \\
+ \text { routine treatment / } \\
\text { routine treatment }\end{array}$ & $\begin{array}{l}2 \text { times/day } \\
2 \text { weeks }\end{array}$ & $\begin{array}{l}\text { Diaphragmatic } \\
\text { mobility }{ }^{*} \\
\text { FEVI } \uparrow^{*} \\
\text { FEVI/FVC } \uparrow^{*}\end{array}$ \\
\hline $\begin{array}{l}\text { Chang et } a^{85} \\
2017\end{array}$ & $\begin{array}{l}\text { Randomized } \\
\text { control trial }\end{array}$ & $\begin{array}{l}\text { Experimental } \\
\text { group/control } \\
\text { group }\end{array}$ & $33 / 32$ & $\begin{array}{l}\text { External diaphragm pacing } \\
+ \text { routine treatment / } \\
\text { routine treatment }\end{array}$ & $\begin{array}{l}\text { I time/day } \\
\text { I4 days }+5 \text { times/ } \\
\text { week } 3 \text { months }\end{array}$ & $\begin{array}{l}\text { MIP }{ }^{*} \\
6 \mathrm{MWD} \uparrow *\end{array}$ \\
\hline 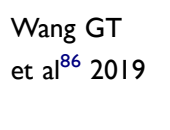 & $\begin{array}{l}\text { Randomized } \\
\text { control trial }\end{array}$ & $\begin{array}{l}\text { Experimental } \\
\text { group/control } \\
\text { group }\end{array}$ & $30 / 30$ & $\begin{array}{l}\text { External diaphragm pacing } \\
+ \text { routine treatment / } \\
\text { routine treatment }\end{array}$ & $\begin{array}{l}2 \text { times/day } \\
14 \text { days }\end{array}$ & $\begin{array}{l}\mathrm{FEVI} \uparrow^{* \& \#} \\
\mathrm{FEVI} / \mathrm{FVC} \uparrow^{\& \& \#} \\
\mathrm{MVV} \uparrow^{\& \& \#}\end{array}$ \\
\hline $\begin{array}{l}\text { Li et al }{ }^{87} \\
2019\end{array}$ & $\begin{array}{l}\text { Randomized } \\
\text { control trial }\end{array}$ & $\begin{array}{l}\text { Experimental } \\
\text { group/control } \\
\text { group }\end{array}$ & $49 / 49$ & $\begin{array}{l}\text { External diaphragm pacing } \\
+ \text { routine treatment / } \\
\text { routine treatment }\end{array}$ & $\begin{array}{l}\text { I time/day } \\
20 \text { days }\end{array}$ & $\begin{array}{l}\text { FEVI\%pred } \uparrow^{* \& \#} \\
\text { FEVI/FVC } \uparrow^{* \& \#}\end{array}$ \\
\hline $\begin{array}{l}\text { Zeng et al }{ }^{88} \\
2019\end{array}$ & Self-control trial & $\begin{array}{l}\text { Moderate } \\
\text { group/severe } \\
\text { group/very } \\
\text { severe group; } \\
\text { group B/group } \\
\text { C/group D }\end{array}$ & 32 & External diaphragm pacing & $\begin{array}{l}2 \text { times/day } \\
20 \text { days }\end{array}$ & $\begin{array}{l}6 \mathrm{MWD} \uparrow^{\&} \\
\mathrm{FEVI}: \\
\text { severe group } \uparrow^{\&} \\
\text { very severe group } \uparrow^{\&} \\
\text { group } \mathrm{C} \uparrow^{\&} \\
\text { group } \mathrm{D} \uparrow^{\&} \\
\mathrm{mMRC} \\
\text { severe group } \downarrow^{\text {\& }} \\
\text { very severe group } \downarrow^{\text {\& }} \\
\text { group } D \downarrow^{\text {\& }}\end{array}$ \\
\hline $\begin{array}{l}\text { You et al }{ }^{89} \\
2018\end{array}$ & $\begin{array}{l}\text { Randomized } \\
\text { control trial }\end{array}$ & $\begin{array}{l}\text { Experimental } \\
\text { group/control } \\
\text { group }\end{array}$ & $30 / 30$ & $\begin{array}{l}\text { External diaphragm pacing } \\
+ \text { routine treatment / } \\
\text { routine treatment }\end{array}$ & $\begin{array}{l}\text { I time/day } \\
\text { I5 days }\end{array}$ & $\begin{array}{l}\mathrm{FEVI} \uparrow^{* \& \#} \\
\mathrm{FVC} \uparrow^{* \& \#} \\
6 \mathrm{MWD} \uparrow^{* \# \#}\end{array}$ \\
\hline $\begin{array}{l}\text { Cao et al }{ }^{90} \\
2018\end{array}$ & Grouping trial & $\begin{array}{l}\text { Experimental } \\
\text { group/control } \\
\text { group }\end{array}$ & $30 / 30$ & $\begin{array}{l}\text { External diaphragm pacing } \\
(2.5 \mathrm{~Hz}+40 \mathrm{~Hz}) / \text { external } \\
\text { diaphragm pacing }(40 \mathrm{~Hz})\end{array}$ & $\begin{array}{l}\text { I time/day } \\
20 \text { days }\end{array}$ & $\begin{array}{l}\text { FEVI\%pred } \uparrow^{* \& \#} \\
\text { FEVI/FVC } \uparrow^{* \& \#} \\
\text { FVC } \uparrow^{\& \#} \\
\text { MMEF }{ }^{\& \#} \\
6 \text { MWD }^{* \& \#}\end{array}$ \\
\hline
\end{tabular}

Notes: *Statistical difference between experimental and control groups $(\mathrm{P}<0.05)$; ${ }^{\circledR}$ statistical difference between experimental groups before and after the experiment $(\mathrm{P}<0.05)$; ${ }^{\#}$ statistical difference between control groups before and after the experiment $(\mathrm{P}<0.05)$; $\uparrow$, increase; $\downarrow$, decrease.

Abbreviations: 6MWD, 6-minute walking distance; FEVI, forced expiratory volume in one second; FEVI\%pred, the percentage of predicted values of FEVI; FVC, forced vital capacity; MIP, maximal inspiratory pressure; MMEF, maximal mid-expiratory flow; mMRC, modified Medical Research Council Dyspnea Scale; MVV, maximal voluntary ventilation. 


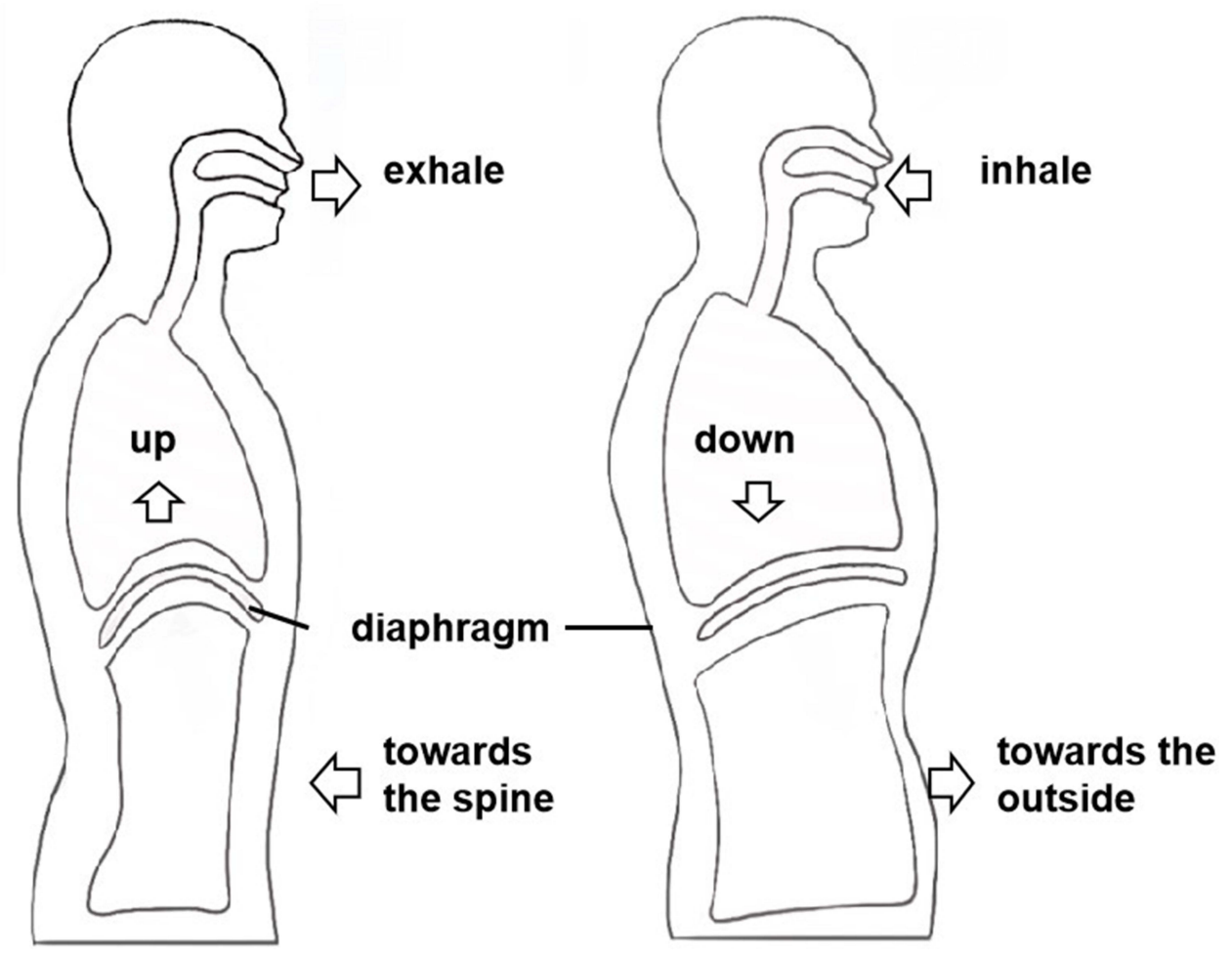

Figure 2 Diaphragmatic breathing.

Notes: When the patient inhales, the abdominal wall moves outward and the diaphragm descends; when the patient exhales, the abdominal wall relaxes and the diaphragm rises.

\section{Suggestions for the Application of Diaphragmatic Breathing Training}

Diaphragmatic breathing was previously reported to be harmful to people with severe respiratory diseases, exacerbating breathing difficulties and disrupting respiratory function. ${ }^{63,64}$ Gosselink et al ${ }^{65}$ reported that the mechanical efficiency of breathing is significantly reduced in patients with severe COPD after diaphragmatic breathing intervention; no obvious changes in tidal volume and respiratory rate occur during breathing, and the feeling of dyspnea increases. Vitacca et al ${ }^{66}$ showed that tidal volume, dyspnea, and inspiratory muscle force increase and respiratory rate decreases. The difference in the results of the above ventilatory function may be related to the manner that the technology was used or to the severity of a patient's illness. In recent studies, most patients involved in diaphragm breathing training are grades II and III, and exacerbated dyspnea has not been reported. This method should be used with caution for patients with grade IV COPD.

Diaphragmatic rehabilitation using diaphragmatic breathing can effectively improve diaphragmatic dysfunction, dyspnea, lung ventilation, and exercise capacity with stable COPD. It is suitable for patients with mild to moderate stable COPD. The advantages of diaphragmatic breathing are as follows. First, it is simple and easy to implement, requiring little in the way of implementation sites, and can be performed in hospital and home environments. Second, it is relatively safe, can be performed independently by conscious patients after professional guidance, and can be used as a home rehabilitation training measure. Third, it is inexpensive, requires only the participation of therapists and patients, and does not require expensive equipment. Fourth, it is flexible and can be combined with other rehabilitation methods according to clinical needs. However, single diaphragmatic breathing training is repeatedly monotonous and boring, which does not stimulate patients' interest and affects their motivation and compliance. If more effective training benefits are desired, diaphragmatic breathing should be combined with other types of methods, such as threshold inspiratory muscle trainer and aerobic exercise. ${ }^{67-71}$ 


\section{Manual Therapy}

Manual therapy is a common method used by rehabilitation therapists. It is widely used in the treatment of musculoskeletal dysfunction and internal diseases. Commonly used diaphragm manual treatments for patients with COPD include diaphragm release technique and diaphragm stretching technique. ${ }^{72,73}$ Both techniques achieve the distraction or release of the anterior part of the diaphragm during respiration by expanding the diameter of the anterolateral lower edge of the thorax. The aim is to increase thoracic mobility, enhance oxygen transport and lymphatic return, and improve respiratory efficiency while promoting autonomic regulation, vasodilation, and smooth muscle relaxation, thus improving diaphragmatic mobility. ${ }^{74}$

Diaphragm release requirements are shown in Figure 3. The subject is asked to lie supine with all four limbs relaxed. The therapist stands on the cephalad side of the patient and uses the hypothenar and three fingers on the ulnar side to reach the inferior aspect of the seventh cartilage to the tenth rib cartilage. The therapist's forearms are aligned with the subject's shoulders. During the inhalation phase, as the rib cage is raised, the therapist gently pulls the point of contact of the hands toward the head and slightly outward. On exhalation, the therapist's hands are deepened toward the inner edge of the rib cage, maintaining resistance. In subsequent breathing cycles, the therapist gradually deepens the contact of the hands toward the inner edge of the rib cage. ${ }^{72}$

Diaphragm stretching requirements are displayed in Figure 4. The subject receives intervention in a seated position. The therapist stands behind the patient with his or her hands around the thorax and introduces his fingers at the lower edge of the rib cage. The subject's trunk is slightly flexed to relax the rectus abdominis muscle. As the subject exhales, the therapist pulls on the lower edge of the lower rib cage with his or her hands. As the patient inhales, traction is maintained to keep the diaphragm in tension. The tension lasts for 5-7 $\min ^{75}$

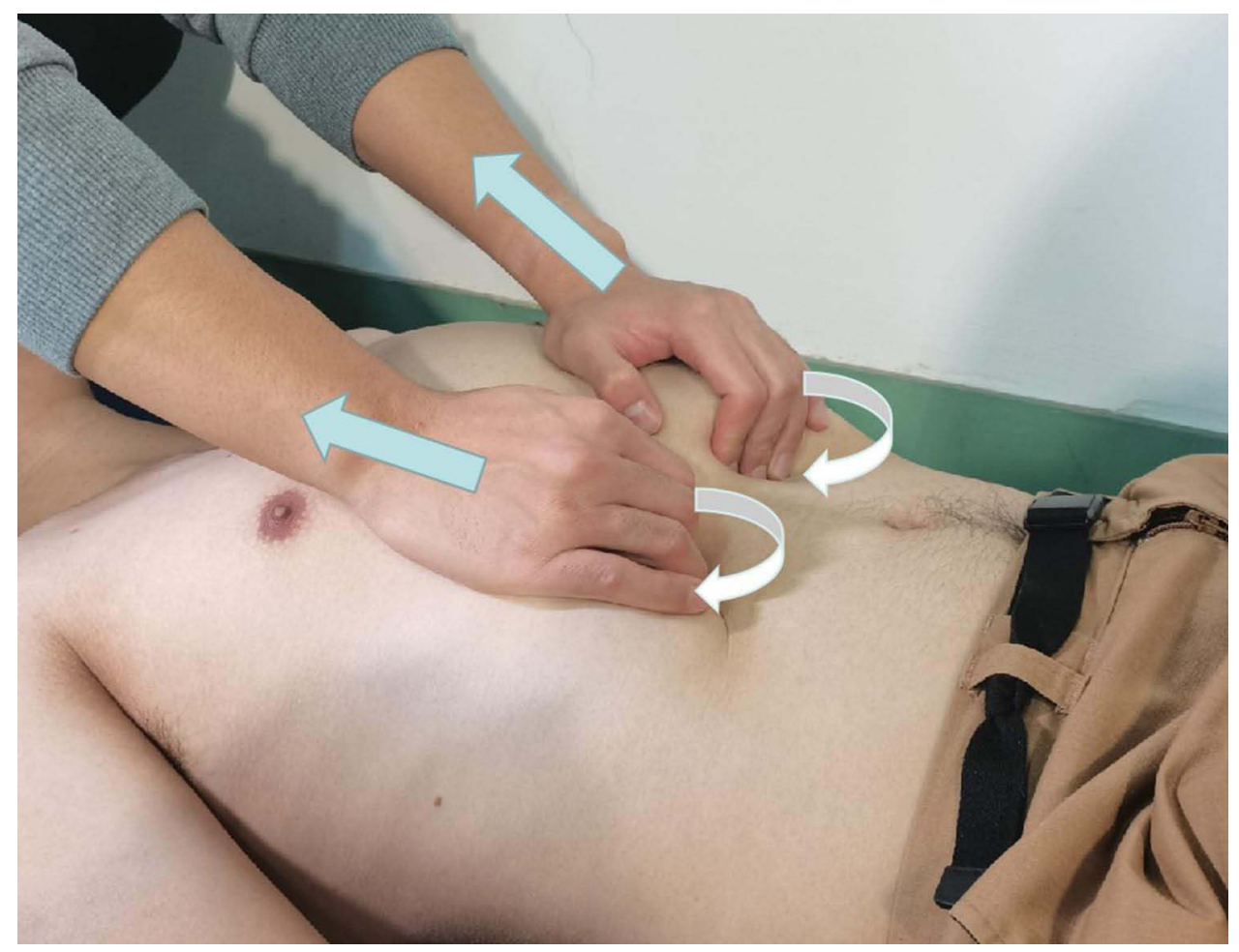

Figure 3 Diaphragm release technique.

Notes: The subject was lying supine. The therapist stands on the cephalic side of the patient and reaches the inferior aspect of the seventh cartilage to the tenth rib cartilage with the ulnar side of the hypothenar and three fingers. The therapist's forearm is aligned with the subject's shoulder. During the inhalation phase, the therapist gently lifts up the chest, pulling the point of contact of the hands toward the head and slightly outward. On exhalation, the therapist's hands are deepened toward the inner edge of the thorax, maintaining resistance. During subsequent breathing cycles, the therapist gradually deepens the contact of the hands toward the inner edge of the chest cavity. $\Rightarrow$ The direction of the therapist's hand force when the subject inhales; the direction of the therapist's hand force when the subject exhales. 


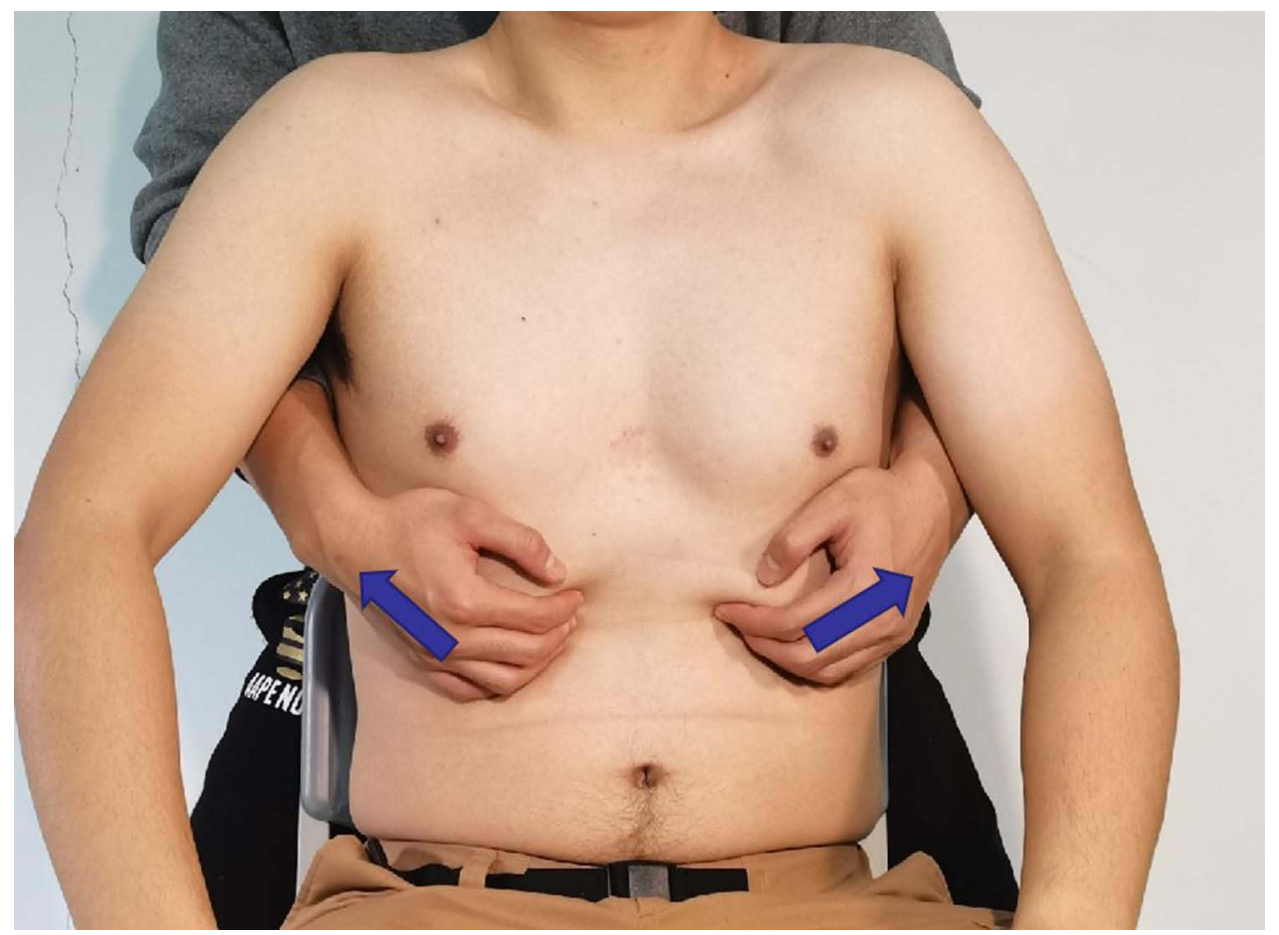

Figure 4 Diaphragm stretching technique.

Notes: The subject sits with the trunk slightly flexed. The therapist stands behind the patient with his or her hands around the chest and places his or her fingers at the lower edge of the rib cage. As the subject exhales, the therapist pulls on the lower edge of the rib cage with his or her hands. As the patient inhales, the traction is maintained to keep the diaphragm under tension. $\Rightarrow$ Direction of force of the therapist's hand as the subject breathes.

\section{Clinical Application of Manual Therapy}

The diaphragmatic release technique improves diaphragmatic mobility, pulmonary function, and exercise capacity in patients with stable COPD (Table 2). Rocha et $\mathrm{al}^{72}$ found that after clinically stable COPD patients received six discontinuous diaphragmatic muscle release treatments within 2 weeks, the diaphragm mobility and 6MWD increased relative to that of the control group, and the inspiratory volume of the experimental group increased to $330 \mathrm{~mL}$. Susmitha et $\mathrm{al}^{76}$ reported that diaphragmatic release technique and conventional diaphragmatic strengthening training (resistance applied at the rib cage during inspiration) significantly improve diaphragmatic mobility and exercise capacity in the patients, but the former technique shows superior results to the latter. Diaphragmatic stretching techniques improve diaphragmatic mobility in patients with COPD. Nair et $\mathrm{al}^{74}$ found an immediate improvement in diaphragm mobility in patients with mild to moderate COPD after intervention with diaphragm stretching techniques, with no significant difference with diaphragm release techniques.

\section{Suggestions for the Application of Manual Therapy}

Diaphragmatic release technique and diaphragmatic stretching technique show no significant difference in improving diaphragmatic mobility in a short time. Apart from diaphragmatic mobility, diaphragmatic release techniques can also improve inspiratory capacity and exercise capacity in patients with COPD. Diaphragmatic release techniques are beneficial not only for patients with COPD but also for those with other diseases involving diaphragmatic dysfunction. Li et $\mathrm{al}^{77}$ found that combining the diaphragm release technique with inspiratory muscle training can significantly improve pulmonary ventilation and inspiratory muscle function in stroke patients. The diaphragm release technique is an effective rehabilitation treatment that improves diaphragm dysfunction, and its use for treating diseases with respiratory muscle involvement, especially diaphragm involvement, is worth promoting.

In addition to the effect on diaphragmatic mobility, diaphragmatic stretching provides immediate improvement in pulmonary function and joint mobility in healthy adults. Gonzalez et $\mathrm{al}^{73,75}$ found that diaphragm stretching improves pulmonary function in healthy adults in a short period. The maximal respiratory pressure, FVC, and FEV1 significantly 
improve after 5 and $20 \mathrm{~min}$ of stretching treatment. Diaphragm stretching improves cervical mobility, posterior chain muscle group flexibility, and thoracic mobility at the xiphoid level in healthy adults compared with those in the controls. The investigators concluded that diaphragm stretching not only improves the function of the diaphragm itself but also causes the contraction of the muscle chain. These effects lead to changes in the range of motion of the other distal structures, thereby improving posterior chain muscle group flexibility and spinal flexibility. Patients with COPD develop a "barrel chest" deformity with a stiff chest wall and reduced flexibility. ${ }^{78}$ However, no study focused on the changes in the posterior chain muscle groups after diaphragmatic stretching techniques in patients with COPD. The study of Gonzalez et al is a great foundation for an in-depth discussion of the influence of diaphragm stretching technique on the musculoskeletal function of patients with COPD.

Diaphragmatic manual therapy is indicated for patients with limited mobility but clear cognition. It requires a trained respiratory therapist to instruct a patient one-on-one, and the patient must cooperate with the therapist's instructions. Other techniques that can be used for patients with COPD include soft tissue therapy and spinal manipulation. A systematic review on manual therapy in patients with COPD reported that manual therapy exerts no effect on the pulmonary function of patients with COPD, which contradicts the results of several diaphragmatic manual therapy trials mentioned above. ${ }^{79}$ Four of the six studies in the systematic review reported joint-like techniques or soft tissue therapies and showed negative pulmonary function results, except the diaphragmatic release technique studied by Rocha et al. ${ }^{72}$ One study showed positive results for respiratory muscle distraction techniques. Inconsistent evaluation may be due to the high heterogeneity of inclusion criteria, types of manipulation, and outcome indicators. Large samples of randomized controlled trials are needed to assess the clinical significance of different manipulative treatments in patients with COPD. Manual therapy can be considered an adjunctive treatment modality to a comprehensive pulmonary rehabilitation program.

\section{Phrenic Nerve Electrical Stimulation}

Diaphragm electrical stimulation methods include internal diaphragm pacing and external diaphragm pacing. Internal diaphragmatic pacing has potential risks, such as damage to the phrenic nerve and chemical stimulation. Xie et al ${ }^{80}$ designed and developed an external diaphragm pacing technique based on internal diaphragmatic pacing (Figure 5). This technique is easy to operate and noninvasive.

\section{Clinical Application of Phrenic Nerve Electrical Stimulation}

We included nine studies of external diaphragm pacing in patients with COPD (Table 3). Four studies demonstrated that external diaphragm pacing improves diaphragmatic dysfunction in patients with $\mathrm{COPD} .{ }^{82-85}$ Wang et $\mathrm{al}^{83}$ reported that diaphragm mobility is higher than baseline after intervention. Three studies found that after the intervention, the external diaphragm pacing group has greater diaphragmatic mobility than the control group. ${ }^{82-84}$ Two studies reported that MIP is

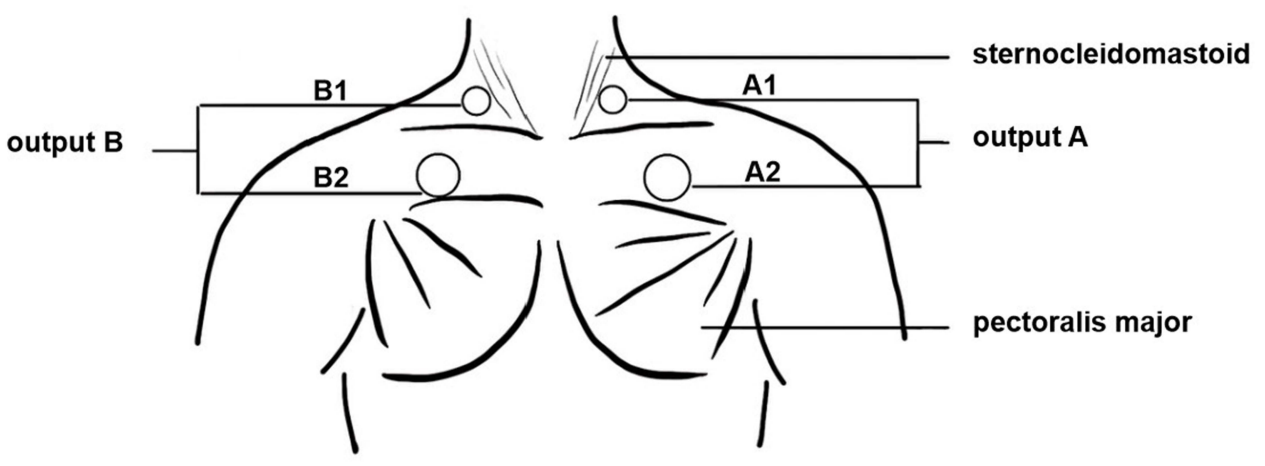

Figure 5 External diaphragm pacing.

Notes: Paste the polar plates on AI, A2, BI, B2 to form a loop. Turning on the machine stimulates the phrenic nerve, producing a nerve impulse that causes the diaphragm to contract. AI, A output channel cathode (small polar plate); A2, A output channel anode (large polar plate); BI, B output channel cathode (small polar plate); B2, B output channel anode (large polar plate); the small polar plate is attached to the lower I/3 of the outer edge of the left and right sternocleidomastoid muscle, respectively; the large polar plate is placed on the surface of the left and right pectoralis major muscles, respectively. Data from Xie. ${ }^{81}$ 
higher than the control group after external diaphragm pacing intervention. ${ }^{82,85}$ Only Cao et al ${ }^{82}$ reported the results of diaphragm thickness after external diaphragm pacing intervention, and no significant difference was found between the intervention and control groups. This result suggests that the improvement of diaphragm function by external diaphragm pacing is limited. In addition, the intervention was possibly not long enough, and the included participants were not very ill.

The pulmonary ventilation function of patients with COPD clearly improves after external diaphragm pacing. Eight studies reported changes in pulmonary ventilation function. ${ }^{82-84,86-90}$ Four of these studies reported FEV1, ${ }^{83,86,88,89}$ two studies reported FEV1\%pred, ${ }^{87,90}$ three studies reported FVC, ${ }^{83,89,90}$ four studies reported FEV1/FVC,${ }^{83,86,87,90}$ Cao et al ${ }^{90}$ reported MMEF, and Wang et $\mathrm{al}^{86}$ reported MVV, with significant differences compared with baseline. Compared with the controls, three studies reported FEV1, ${ }^{84,86,89}$ three studies reported FEV1\% $\%$ pred,${ }^{82,87,90}$ two studies reported FVC, ${ }^{83,89}$ four studies reported FEV1/FVC, ${ }^{84,86,87,90}$ and Wang GT et al ${ }^{86}$ reported MVV, with better results in the intervention group than the control group.

Four studies reported the effect of external diaphragm pacing on exercise capacity in patients with COPD. ${ }^{85,88-90}$ Three studies reported prolongation of 6MWD after the intervention compared with pre-treatment. ${ }^{88-90}$ Three studies reported superior 6MWD in the intervention group compared with the control group. ${ }^{85,89,90}$ This result shows that external diaphragm pacing can improve the exercise capacity of patients with COPD.

Zeng et $\mathrm{al}^{88}$ reported a reduction in mMRC scores compared with pre-treatment, but only among patients at a severe stage of the disease.

\section{Suggestions for the Application of Phrenic Nerve Electrical Stimulation}

External diaphragm pacing improves diaphragmatic dysfunction, pulmonary ventilation, exercise capacity, and dyspnea in patients with COPD. In terms of benefit, external diaphragmatic pacing is effective in the treatment of severely and very severely treated patients. ${ }^{88}$ In terms of treatment frequency, using compound frequencies is more effective than using physiological frequencies. ${ }^{90}$ The disadvantage is that as a passive treatment, it is not effective in treating mild patients. ${ }^{88}$ It requires the accurate localization of the stimulation point. External diaphragm pacing is a worthwhile technique to incorporate into a pulmonary rehabilitation program when the development of active treatment methods is limited.

\section{Conclusion}

Diaphragmatic dysfunction in patients with COPD is characterized by decreased mobility and muscle strength, and increased thickening. The reduction in diaphragm thickness was only observed in severe patients, and changes in diaphragm thickness in mild-to-moderate patients require additional studies. Appropriate assessment and treatment must be selected for diaphragmatic dysfunction in patients with COPD. Ultrasound is a commonly used method of diaphragmatic assessment, which can be used to assess diaphragmatic mobility, thickness, and thickening. Diaphragmatic muscle strength can be assessed using Pdi and MIP. Targeted rehabilitation measures for diaphragmatic dysfunction in patients with COPD include diaphragmatic breathing, manual therapy, and phrenic nerve stimulation. Targeted rehabilitation measures for diaphragmatic dysfunction in patients with COPD can improve diaphragm function, pulmonary ventilation function, dyspnea, and exercise capacity.

Owing to the anatomical characteristics of the diaphragm, most studies only assessed the effects of diaphragm rehabilitation therapy on diaphragm dysfunction in an indirect way. A direct, non-invasive and standardized assessment for diaphragm dysfunction is required. Multi-center and large-sample randomized controlled clinical trials should be conducted to investigate the intervention effects and mechanisms of different diaphragm rehabilitation treatment modalities. It will provide effective guidance for the development and selection of diaphragmatic assessments and rehabilitation therapies for COPD.

\section{Acknowledgments}

The authors would like to thank Mr Jian Li, Mr Zhaoyu Yang for their manual therapy demonstration. This work was supported by the National Natural Science Foundation of China (No 82072551 and No 81902307). 


\section{Disclosure}

The authors report no conflicts of interest in this work.

\section{References}

1. Global initiative for chronic obstructive lung disease. Global strategy for the diagnosis, management, and prevention of chronic obstructive pulmonary disease 2022 Report; 2022. Available from: https://goldcopd.org/2022-gold-reports-2/. Accessed January 5, 2022.

2. Wang $\mathrm{C}, \mathrm{Xu}$ J, Yang L, et al. Prevalence and risk factors of chronic obstructive pulmonary disease in China (the China Pulmonary Health [CPH] study): a national cross-sectional study. Lancet. 2018;391(10131):1706-1717. doi:10.1016/s0140-736(18)30841-9

3. Rabe KF, Watz H. Chronic obstructive pulmonary disease. Lancet. 2017;389(10082):1931-1940. doi:10.1016/S0140-6736(17)31222-9

4. Zhu BF, Wang YF, Ming J, et al. Disease burden of COPD in China: a systematic review. Int J Chronic Obstr. 2018;13:1353-1364. doi:10.2147/ COPD.S161555

5. Ratnovsky A, Elad D. Anatomical model of the human trunk for analysis of respiratory muscles mechanics. Respir Physiol Neurobiol. 2005;148 (3):245-262. doi:10.1016/j.resp.2004.12.016

6. Doucet M, Debigare R, Joanisse DR, et al. Adaptation of the diaphragm and the vastus lateralis in mild-to-moderate COPD. Eur Respir J. 2004;24 (6):971-979. doi:10.1183/09031936.04.00020204

7. Ottenheijm CA, Heunks LM, Dekhuijzen RP. Diaphragm adaptations in patients with COPD. Respir Res. 2008;12(9):1-14. doi:10.1186/14659921-9-12

8. Gea J, Agustí A, Roca J. Pathophysiology of muscle dysfunction in COPD. J Appl Physiol. 2013;114(9):1222-1234. doi:10.1152/ japplphysiol.00981.2012

9. Levine S, Bashir MH, Clanton TL, et al. COPD elicits remodeling of the diaphragm and vastus lateralis muscles in humans. $J$ Appl Physiol. 2013;114(9):1235-1245. doi:10.1152/japplphysiol.01121.2012

10. Santana PV, Albuquerque AL. Respiratory muscles in COPD: be aware of the diaphragm. J Bras Pneumol. 2018;44(1):1-2. doi:10.1590/S180637562018000010001

11. Fu XM, Wang JH, Pan DZ, et al. Diaphragmatic mobility function and its correlation with pulmonary function in patients with COPD. Chin Gen Pract. 2021;24(5):561-565,576. Chinese. doi:10.12114/j.issn.1007-9572.2020.00.329

12. Boon AJ, O'Gorman C. Ultrasound in the assessment of respiration. J Clin Neurophysiol. 2016;33(2):112-119. doi:10.1097/ WNP.0000000000000240

13. Ottenheijm CA, Heunks LM, Sieck GC, et al. Diaphragm dysfunction in chronic obstructive pulmonary disease. Am J Respir Crit Care Med. 2005;172(2):200-205. doi:10.1164/rccm.200502-262OC

14. Hellebrandova L, Chlumsky J, Vostatek P, et al. Airflow limitation is accompanied by diaphragm dysfunction. Physiol Res. 2016;65(3):469-479. doi:10.33549/physiolres.933064

15. Shiraishi M, Higashimoto Y, Sugiya R, et al. Diaphragmatic excursion correlates with exercise capacity and dynamic hyperinflation in COPD patients. ERJ Open Res. 2020;6(4):00589-2020. doi:10.1183/23120541.00589-2020

16. Hida T, Yamada Y, Ueyama M, et al. Decreased and slower diaphragmatic motion during forced breathing in severe COPD patients: time-resolved quantitative analysis using dynamic chest radiography with a flat panel detector system. Eur $J$ Radiol. 2019;112:28-36. doi:10.1016/j. ejrad.2018.12.023

17. Zhang LJ, Zhu XP. Ultrasonographic assessment of the diaphragm mobility in patients with chronic obstructive pulmonary disease: relationships with pulmonary function and BODE index. J Ningxia Med Univ. 2017;39(05):534-536+483. Chinese. doi:10.16050/j.cnki.issn16746309.2017.05.011

18. Dai BZ, Ren CF, Zheng QL, et al. Relation between diaphragm function and CAT in patients with COPD. J Clin Pulm Med. 2015;20(04):690-692. Chinese. doi:10.3969/j.issn.1009-6663.2015.04.036

19. Paulin E, Yamaguti WP, Chammas MC, et al. Influence of diaphragmatic mobility on exercise tolerance and dyspnea in patients with COPD. Respir Med. 2007;101(10):2113-2118. doi:10.1016/j.rmed.2007.05.024

20. Liu M, Pian LP. The relationship of diaphragmatic mobility evaluated by ultrasonography with quality of life and athletic ability in patients with chronic obstructive pulmonary disease. Chin J Respir Crit Care Med. 2018;17(06):548-551. Chinese. doi:10.7507/1671-6205.201804041

21. Zheng ZG, Chen RC, Zhang XY, et al. Comparison of different methods in assessing diaphragmatic muscle function and their application in patients with COPD. Chin J Pract Int Med. 2003;9:530-532. Chinese. doi:10.3969/j.issn.1005-2194.2003.09.004

22. Polkey MI, Kyroussis D, Hamnegard CH, et al. Diaphragm strength in chronic obstructive pulmonary disease. Am J Respir Crit Care Med. 1996;54 (5):1310-1317. doi:10.1164/ajrccm.154.5.8912741

23. Souza RM, Cardim AB, Maia TO, et al. Inspiratory muscle strength, diaphragmatic mobility, and body composition in chronic obstructive pulmonary disease. Physiother Res Int. 2019;24(2):1766. doi:10.1002/pri.1766

24. Aziz AA, Elwahsh RA, Abdelaal GA, et al. Diaphragmatic assessment in COPD patients by different modalities. Egypt $J$ Chest Dis Tuberc. 2017;66(2):247-250. doi:10.1016/j.ejcdt.2017.03.006

25. Tudorache V, Oancea C, Mladinescu OF. Clinical relevance of maximal inspiratory pressure: determination in COPD exacerbation. Int J Chronic Obstr. 2010;5:119-123. doi:10.2147/copd.s9194

26. Yu BX, Huang NQ, Liu YN, et al. Examination of maximum transdiaphragmatic pressure, diaphragm electromyography in patients with obstructive emphysema. Acad J Chin PLA Med Sch. 1992;3:250-252. Chinese.

27. Baria MR, Shahgholi L, Sorenson EJ, et al. B-mode ultrasound assessment of diaphragm structure and function in patients with COPD. Chest. 2014;146(3):680-685. doi:10.1378/chest.13-2306

28. Zhang LJ, Zhu XP. Correlation between diaphragm thickness and pulmonary function in patients with COPD. Ningxia Med J. 2017;39(6):4. Chinese. doi:10.13621/j.1001-5949.2017.06.0491

29. Smargiassi A, Inchingolo R, Tagliaboschi L, et al. Ultrasonographic assessment of the diaphragm in chronic obstructive pulmonary disease patients: relationships with pulmonary function and the influence of body composition-A pilot study. Respiration. 2014;87(5):364-371. doi:10.1159/ 000358564 
30. Rittayamai N, Chuaychoo B, Tscheikuna J, et al. Ultrasound evaluation of diaphragm force reserve in patients with chronic obstructive pulmonary disease. Ann Am Thorac Soc. 2020;17(10):1222-1230. doi:10.1513/AnnalsATS.202002-129OC

31. Eryuksel E, Cimit C, Bekir M, et al. Diaphragmatic thickness fraction in subjects at high-risk for COPD exacerbations. Respir Care. 2017;62 (12):1565-1570. doi:10.4187/respcare.05646

32. Barreiro E, Gea J. Respiratory and limb muscle dysfunction in COPD. COPD. 2015;12(4):413-426. doi:10.3109/15412555.2014.974737

33. Testelmans D, Crul T, Maes K, et al. Atrophy and hypertrophy signalling in the diaphragm of patients with COPD. Eur Respir J. 2010;35 (3):549-556. doi:10.1183/09031936.00091108

34. Zhang Y, Gao J, Luo Y. The effect of various durations of cigarette smoke exposure on muscle fibre remodeling in rat diaphragms. Biomed Pharmacother. 2019;117:109503. doi:10.1016/j.biopha.2019.109053

35. Geiger PC, Cody MJ, Macken RL, et al. Maximum specific force depends on myosin heavy chain content in rat diaphragm muscle fibers. $J$ Appl Physiol. 2000;89(2):695-703. doi:10.1152/jappl.2000.89.2.695

36. Barreiro E, Ferrer D, Sanchez F, et al. Inflammatory cells and apoptosis in respiratory and limb muscles of patients with COPD. J Appl Physiol. 2011;111(3):808-817. doi:10.1152/japplphysiol.01017.2010

37. Barreiro E, de la Puente B, Minguella J, et al. Oxidative stress and respiratory muscle dysfunction in severe chronic obstructive pulmonary disease. Am J Respir Crit Care Med. 2005;171(10):1116-1124. doi:10.1164/rccm.200407-8870C

38. Marin-Corral J, Minguella J, Ramirez-Sarmiento AL, et al. Oxidised proteins and superoxide anion production in the diaphragm of severe COPD patients. Eur Respir J. 2009;33(6):1309-1319. doi:10.1183/09031936.00072008

39. Ottenheijm CA, Heunks LM, Li YP, et al. Activation of the ubiquitin-proteasome pathway in the diaphragm in chronic obstructive pulmonary disease. Am J Respir Crit Care Med. 2006;174(9):997-1002. doi:10.1164/rccm.200605-721OC

40. Wang FF, Zhu XP, Ma SL. Ultrasonographic evaluation of diaphragm structure and function. Chin Crit Care Med. 2017;29(03):276-280. doi:10.3760/cma.j.issn.2095-4352.2017.03.018.Chinese

41. Boussuges A, Gole Y, Blanc P. Diaphragmatic motion studied by m-mode ultrasonography: methods, reproducibility, and normal values. Chest. 2009;135(2):391-400. doi:10.1378/chest.08-1541

42. Zhou LN, Li QY, Huang SG. Research progress of comprehensive evaluation methods for diaphragmatic dysfunction. Chin J Tuberc Respir Dis. 2014;37(02):115-118. Chinese. doi:10.3760/cma.j.issn.1001-0939.2014.02.011

43. Yang MZ, Li F. Research progress of diaphragm function. Chin J Phys Med Rehabil. 2019;8:623-626. Chinese. doi:10.3760/cma.j.issn.02541424.2019.08.019

44. Toshiaki K, Shohei M, Kazuhisa T, et al. An analysis of chest wall and diaphragm motions in patients with idiopathic scoliosis using dynamic breathing MRI. Spine. 2004;29(3):298-302. doi:10.1097/01.brs.0000106490.82936.89

45. Belén A. ATS/ERS Statement on respiratory muscle testing. Am J Respir Crit Care Med. 2002;166(4):518-624. doi:10.1164/rccm.166.4.518

46. McCool FD, Tzelepis GE. Dysfunction of the diaphragm. New Engl J Med. 2012;366(10):932-942. doi:10.1056/NEJMra1007236

47. Laveneziana P, Albuquerque A, Aliverti A, et al. ERS statement on respiratory muscle testing at rest and during exercise. Eur Respir J. 2019;53 (6): 1801214. doi:10.1183/13993003.01214-2018

48. Laghi FA, Saad M, Shaikh H. Ultrasound and non-ultrasound imaging techniques in the assessment of diaphragmatic dysfunction. BMC Pulm Med. 2021;21(1):85. doi:10.1186/s12890-021-01441-6

49. Boon AJ, Harper CJ, Ghahfarokhi LS, et al. Two-dimensional ultrasound imaging of the diaphragm: quantitative values in normal subjects. Muscle Nerve. 2013;47(6):884-889. doi:10.1002/mus.23702

50. Page MJ, McKenzie JE, Bossuyt PM, et al. The PRISMA 2020 statement: an updated guideline for reporting systematic reviews. $B M J .2021 ; 372$ : n71. doi:10.1136/bmj.n71

51. Beaumont M, Forget P, Couturaud F, et al. Effects of inspiratory muscle training in COPD patients: a systematic review and meta-analysis. Clin Respir J. 2018;12(7):2178-2188. doi:10.1111/crj.12905

52. Figueiredo RIN, Azambuja AM, Cureau FV, et al. Inspiratory muscle training in COPD. Respir Care. 2020;65(8):1189-1201. doi:10.4187/ respcare.07098

53. Langer D, Ciavaglia C, Faisal A, et al. Inspiratory muscle training reduces diaphragm activation and dyspnea during exercise in COPD. $J$ Appl Physiol. 2018;125(2):381-392. doi:10.1152/japplphysiol.01078.2017

54. Xia JG, Ba WT. Diaphragmatic dysfunction and respiratory muscle training in chronic obstructive pulmonary disease. Chin J Tuberc Respir Dis. 2021;44(9):775-778. Chinese. doi:10.3760/cma.j.cn112147-20210514-00332

55. Clini E, Holland AE, Pitta F, Troosters T. Textbook of Pulmonary Rehabilitation. Ist ed. Beijing: People's Medical Publishing House; 2019. Chinese

56. Morrow B, Brink J, Grace S, et al. The effect of positioning and diaphragmatic breathing exercises on respiratory muscle activity in people with chronic obstructive pulmonary disease. S Afr J Physiother. 2016;72(1):315. doi:10.4102/sajp.v72i1.315

57. Cahalin LP, Braga M, Matsuo Y, et al. Efficacy of diaphragmatic breathing in persons with chronic obstructive pulmonary disease: a review of the literature. J Cardiopulm Rehabil. 2002;22(1):7-21. doi:10.1097/00008483-200201000-00002

58. Hamasaki H. Effects of diaphragmatic breathing on health: a narrative review. Medicines. 2020;7(10):65. doi:10.3390/medicines7100065

59. Yamaguti WP, Claudino RC, Neto AP, et al. Diaphragmatic breathing training program improves abdominal motion during natural breathing in patients with chronic obstructive pulmonary disease: a randomized controlled trial. Arch Phys Med Rehabil. 2012;93(4):571-577. doi:10.1016/j. apmr.2011.11.026

60. Ma BR. The effect of modified abdominal breathing training method on patients with chronic obstructive pulmonary disease. $J$ Comm Med. 2014;12(09):69-71. Chinese.

61. Liu J, You YQ. Effect of flexed abdominal breathing training on the efficacy of remission in elderly patients with chronic obstructive pulmonary disease. Jilin Med J. 2011;32(34):7385-7386. Chinese. doi:10.3969/j.issn.1004-0412.2011.34.124

62. Zhan SS, Zheng LL. Evaluation of clinical efficacy in guiding the rehabilitation of patients with COPD in remission by abdominal breathing therapy. Health Guide. 2020;8:52. Chinese.

63. Fernandes M, Cukier A, Feltrim MI. Efficacy of diaphragmatic breathing in patients with chronic obstructive pulmonary disease. Chron Respir Dis. 2011;8(4):237-244. doi:10.1177/1479972311424296 
64. Lewis LK, Williams MT, Olds T. Short-term effects on outcomes related to the mechanism of intervention and physiological outcomes but insufficient evidence of clinical benefits for breathing control: a systematic review. Aust J Physiother. 2007;53(4):219-227. doi:10.1016/s00049514(07)70002-8

65. Gosselink RA, Wagenaar RC, Rijswijk H, et al. Diaphragmatic breathing reduces efficiency of breathing in patients with chronic obstructive pulmonary disease. Am J Respir Crit Care Med. 1995;151(4):1136-1142. doi:10.1164/ajrccm.151.4.7697243

66. Vitacca M, Clini E, Bianchi L, et al. Acute effects of deep diaphragmatic breathing in COPD patients with chronic respiratory insufficiency. Eur Respir J. 1998;11(2):408-415. doi:10.1183/09031936.98.11020408

67. Sun N, Li DP, Sun Y. Effect of Liuzijue combined with lip-contracting abdominal breathing training on lung function and quality of life in stable COPD patients. J Clin Res. 2019;36(5):1003-1004. Chinese. doi:10.3969/j.issn.1671-7171.2019.05.061

68. Ji L, Zhang YY, Mao S, et al. Effect of respiratory exerciser tri-ball training in stable COPD patients during pulmonary rehabilitation. J Clin Pulm Med. 2019;24(09):1640-1644. Chinese. doi:10.3969/j.issn.1009-6663.2019.09.022

69. Chen MF, Chen XQ, Huang JH. Effects of labial and abdominal breathing combined with resistance breathing training on lung function and quality of life in elderly patients with chronic obstructive pulmonary disease in stable phase. Chin Nurs Res. 2019;33(20):3509-3512. Chinese. doi:10.12102/j.issn.1009-6493.2019.20.011

70. Feng XL, Jiang Y, Wu DL, et al. Effects of half-closed lip abdominal respiration combined with resistance breathing training device on rehabilitation and quality of life in elderly patients with COPD at stable stage. Pract J Clin Med. 2018;15(02):121-124. Chinese. doi:10.3969/j. issn.1672-6170.2018.02.038

71. Wu HY. Effects of abdominal breathing combined with breathing exercises on quality of life in discharged patients with COPD. Int J Nurs. 2017;36 (12):1723-1725. Chinese. doi:10.3760/cma.j.issn.1673-4351.2017.12.050

72. Rocha T, Souza H, Brandão DC, et al. The manual diaphragm release technique improves diaphragmatic mobility, inspiratory capacity and exercise capacity in people with chronic obstructive pulmonary disease: a randomised trial. J Physiother. 2015;61(4):182-189. doi:10.1016/j. jphys.2015.08.009

73. González-Alvarez FJ, Valenza MC, Torres-Sanchez I, et al. Effects of diaphragm stretching on posterior chain muscle kinematics and rib cage and abdominal excursion: a randomized controlled trial. Braz J Phys Ther. 2016;20(5):405-411. doi:10.1590/bjpt-rbf.2014.0169

74. Nair A, Alaparthi GK, Krishnan S, et al. Comparison of diaphragmatic stretch technique and manual diaphragm release technique on diaphragmatic excursion in chronic obstructive pulmonary disease: a randomized crossover trial. Pulm Med. 2019;2019:1-7. doi:10.1155/2019/6364376

75. González-álvarez FJ, Valenza MC, Cabrera-Martos I, et al. Effects of a diaphragm stretching technique on pulmonary function in healthy participants: a randomized-controlled trial. Int J Osteopath Med. 2015;18(1):5-12. doi:10.1016/j.ijosm.2014.08.001

76. Susmitha P. The effect of manual diaphragmatic release techniques in the improvement of diaphragmatic mobility and exercise capacity in subjects with chronic obstructive pulmonary disease: a comparative study [dissertation]. Nandha: Nandha College of Physiotherapy; 2017.

77. Li LL, Hao SJ, Wang WH, et al. Effect observation of diaphragm release technique combined with inspiratory muscle training on pulmonary function of stroke patients. Rehabil Med. 2018;28(1):19-23. Chinese. doi:10.3724/SP.J.1329.2018.01019

78. Hochhegger B, Meireles GD, Irion K, et al. The chest and aging: radiological findings. J Bras Pneumol. 2012;38(5):656-665. doi:10.1590/s180637132012000500016

79. Simonelli C, Vitacca M, Vignoni M, et al. Effectiveness of manual therapy in COPD: a systematic review of randomised controlled trials. Pulmonology. 2019;25(4):236-247. doi:10.1016/j.pulmoe.2018.12.008

80. Xie BX, Chen JL, Li ZP, et al. Study of rehabilitation for diaphragm function in the chronic obstructive pulmonary disease in external diaphragm pacing I. Infulence of tidal volume in external diaphragm pacing to chronic obstructive pulmonary disease. J Sun Yat-Sen Univ Med Sci. 1987;3:32-36. Chinese.

81. Xie BX. 30 Years of Development and Clinical Application of External Diaphragm Pacing. 1st ed. Changchun: Jilin University Press; 2017. Chinese

82. Cao HL, Zheng HB, Liu ZJ, et al. Effect of external diaphragm pacemaker on balance and gait in patients with chronic obstructive pulmonary disease at stable stage. Chin J Rehab Med. 2020;35(05):581-584. Chinese. doi:10.3969/j.issn.1001-1242.2020.05.013

83. Wang JC. Effects of external diaphragm pacing therapy on cough and expectoration in patients with chronic obstructive pulmonary disease. Wld Latest Med Info. 2019;88:3. Chinese. doi:10.19613/j.cnki.1671-3141.2019.88.013

84. Feng Y. Effect of external diaphragmatic pacing on rehabilitation of patients with chronic obstructive pulmonary disease. Chin J Rural Med Phar. 2019;26(14):50-51. Chinese. doi:10.3969/j.issn.1006-5180.2019.14.031

85. Chang Y. Influence of external diaphragm pacing therapy on hospital stay in patients with COPD. Health Guide. 2017;39:166,157. Chinese. doi:10.3969/j.issn.1006-6845.2017.39.16.6845.2017.39.160

86. Wang GT, Liang SS, Li SM, et al. Analysis of clinical effect of external diaphragm pacemaker in the treatment of COPD patients. Heilongjiang Med Phar. 2019;42(5):2. Chinese. doi:10.3969/j.issn.1006-6845.2017.39.160

87. Li L, Li Q. Effects of external diaphragm pacing on pulmonary function, oxygen metabolism and BODE index in stable COPD patients. $J$ Clin Res. 2019;36(8):1579-1581. Chinese. doi:10.3969/j.issn.1671-7171.2019.08.046

88. Zeng JL, Tan SX, Hu RC, et al. Effect of external diaphragm pacing on pulmonary rehabilitation in stable chronic obstructive pulmonary disease patients. Int J Respir. 2019;39(16):1216-1221. Chinese. doi:10.3760/cma.j.issn.1673-436X.2019.16.004

89. You QY, Huang YL, Yue L. Application effect of external diaphragm pacemaker in stable chronic obstructive pulmonary disease. Chin $J$ Clin Rational Drug Use. 2018;11(3):3. Chinese.

90. Cao HL, Liu ZJ, Jiang HY, et al. Efficacy of ultra-low frequency combined with physiological frequency chronic electrical stimulation for stable COPD. Shandong Med J. 2018;58(40):57-59. Chinese. doi:10.3969/j.issn.1002-266X.2018.40.015 
International Journal of Chronic Obstructive Pulmonary Disease

\section{Publish your work in this journal}

The International Journal of COPD is an international, peer-reviewed journal of therapeutics and pharmacology focusing on concise rapid reporting of clinical studies and reviews in COPD. Special focus is given to the pathophysiological processes underlying the disease, intervention programs, patient focused education, and self management protocols. This journal is indexed on PubMed Central, MedLine and CAS. The manuscript management system is completely online and includes a very quick and fair peer-review system, which is all easy to use. Visit http://www. dovepress.com/testimonials.php to read real quotes from published authors.

Submit your manuscript here: https://www.dovepress.com/international-journal-of-chronic-obstructive-pulmonary-disease-journal 